\title{
SHREWD BARGAINING ON THE MORAL FRONTIER: TOWARD A THEORY OF MORALITY IN PRACTICE*
}

\author{
J. Gregory Dees and Peter C. Cramton
}

\begin{abstract}
From a traditional moral point of view, business practitioners often seem overly concerned about the behavior of their peers in deciding how they ought to act. We propose to account for this concern by introducing a mutual trust perspective, where moral obligations are grounded in a sense of trust that others will abide by the same rules. When grounds for trust are absent, the obligation is weakened. We illustrate this perspective by examining the widespread ambivalence with regard to deception about one's settlement preferences in negotiation. On an abstract level, such deception generally seems undesirable, though in many individual cases it is condoned, even admired as shrewd bargaining. Because of the difficulty in verifying someone's settlement preferences, it is hard to establish a basis for trusting the revelations of the other party, especially in competitive negotiations with relative strangers.
\end{abstract}

Brer Rabbit had got himself caught by Brer Fox and was well on his way to becoming evening dinner. Brer Rabbit was in a great deal of deep trouble.

There didn't seem much he could do about this one, but he didn't seem concerned at all at being the Fox's dinner. He just said, "Brer Fox I don't mind if you eat me. But, oh, whatever you do don't throw me in that briar patch."

Now Brer Fox was surely looking forward to eating his old enemy, but he was mighty curious about Brer Rabbit's sweating and crying about being thrown into the briar patch.

And the more he questioned it the more Brer Rabbit wailed about how much he hated and feared that briar patch.

Pretty soon it did seem that Brer Rabbit would rather be eaten than be set among those briars. So Brer Fox threw Brer Rabbit into the heart of the briar patch. Brer Rabbit gleefully scampered away.

From the tales of Brer Rabbit ${ }^{1}$

$\mathrm{O}^{\circ}$ $\mathrm{NE}$ of the greatest frustrations of applied ethics arises when seemingly flawless logic fails to convince practitioners to take the morally superior course of action. The great temptation is for the ethicist to write off the practitioners as somehow morally or mentally deficient. For their part, the practitioners are likely to regard the ethicist as naively idealistic. This tendency to talk past one another must be resisted if academic ethicists are to avoid what Annette Baier has called "that arrogance of solitary intellect which has condemned much of moral theory to sustained self-delusions concerning its subject matter, its methods, and its authority" (Baier, 1985, p. 244).

This paper is written in an effort to move professional ethicists a notch closer to the world of practice. It uses a puzzle about a common form of deception in negotiation to stimulate the development of a perspective on morality that seems to be common in practice, but is underdeveloped in the literature of applied ethics. The deception that we are concerned with is illustrated in the story about Brer Rabbit, namely deception about one's settlement preferences. We choose this focus, not because we believe it to be one of the most pressing moral issues of the day, but because it is familiar to most readers, and it leads quite naturally to the perspective that we want to introduce in this paper. We call it the Mutual Trust perspective on morality.

To understand the Mutual Trust perspective, it is useful to distinguish between ideal morality and morality in practice. Ideal morality determines the practices, rules, values, virtues, and so on that might be derived a priori from an abstract moral point of view. This is the morality that concerns most philosophical ethicists. Morality in practice, by contrast, takes into account the fact that we live in a morally imperfect, often competitive, sometimes unjust world. The Mutual Trust account of morality in practice tempers ideal morality with concerns about prudence, fair play, and effectiveness, offering a pragmatic approach to moral responsibility. According to the Mutual Trust view, moral obligations rest, at least in part, on a foundation of mutual trust. When that foundation of trust is absent, the obligation is undermined. Specifically, to take risky or imprudent action on the basis of moral ideals, when others cannot be trusted to do the same, may be admirable, but it goes beyond the obligations of morality in practice. ${ }^{2}$

If we are correct that some form of the Mutual Trust perspective is widely accepted by practicing professionals and business people, the implications go far beyond the issue of deception about settlement 
preferences. This approach to morality in practice could be used to justify a wide range of deviations from moral ideals. If we wish to correct those deviations, to move professional conduct closer to the ideals, it will not be sufficient to offer more arguments from an ideal moral point of view. To simply assert the logical dominance of idealistic moral reasoning begs the question. Standard moral arguments will fall on deaf ears. Either we need to convince practitioners to reject this view on less idealistic grounds, or we need to provide more practical advice. Our primary task changes from a purely philosophical one to the more pragmatic job of helping practitioners to minimize the risk of individual moral action, and to build and maintain trust.

In this paper, we offer a first cut at developing the Mutual Trust perspective on morality in practice. Our goal is to do what most practitioners are ill equipped to do for themselves, to present this view in a way that is philosophically coherent and defensible. We do not claim that it is the only defensible approach to morality in practice. It is not our intention to champion or promote it. In fact, we have concerns about it. We simply want to argue that it is a perspective that deserves more serious treatment than it has received to date. ${ }^{3}$

\section{The Puzzle of Deception About Settlement Issues}

Our thoughts about the Mutual Trust perspective developed largely in response to a puzzle that was born out of a frustrating clash between theory and practice. The puzzle concerns a form of deception that commonly occurs in negotiations, deception ${ }^{4}$ about one's preferences regarding the terms, conditions, and timing of a settlement. Settlement-issue deception is so common that some see it as a defining characteristic of negotiation. As lames 1. White, writing in the American Bar Foundation Research Journal, has put it, "To conceal one's true position, to mislead an opponent about one's true settling point, is the essence of negotiation" (White, 1980, p. 928). The puzzle is that, according to standard moral theories, this practice is objectionable, yet it is widely condoned in business and legal negotiations, and even praised, as "shrewd" bargaining when it is successful.

Consider a couple of examples. When the seller of a house coolly asserts that she is in no hurry to sell, even though she is in fact pressured by imminent employment and housing commitments a thousand miles away, she may be taking a negotiating risk, but few would condemn her as unethical in doing this. If this leads a motivated buyer to make a more attractive offer, we may think of her as shrewd. Contrast this attempted deception with her making an assertion that the house is in excellent mechanical condition when she knows that it has a very serious, but hard to detect plumbing problem. The latter is far more troubling, though both involve lies and both (if successful) may cause essentially the same degree of financial harm to the buyer. Secondly, consider a lawyer representing the plaintiff in an accident settlement case. She receives the following instructions from her client: "Try to get as much as you can, but I will accept anything over $\$ 50,000$." When the defendant's lawyers open with a surprisingly high offer of $\$ 65,000$, the plaintiff's lawyer coolly responds, "I do not think I can get my client to settle for that amount. I am hesitant to bring him anything under $\$ 75,000$." Little negotiating risk is taken. She knows that if the other side does not budge, she can "reluctantly" return to the "disappointing offer" of $\$ 65,000$. If the defendant's lawyers raise the offer, her ploy has worked. She has done a better job for her client. Compare misrepresentation of her client's settlement preferences with misrepresenting the extent and nature of her client's injuries. Why don't we condemn deception about settlement issues in the same way that we do other types of deception in negotiation? Why is it that we often applaud the shrewd bargainer who successfully bluffs the opposing party into a favorable agreement, while condemning the person who fraudulently misrepresents her product to the same end? Why do we tell stories such as the legend of Brer Rabbit to our children, when the moral seems to be that the shrewd use of deception is sometimes a good thing?

Using standard forms of ethical argument, a relatively strong prima facie case can be built against the general practice of settlement-issue deception. It raises concerns on Kantian, utilitarian, and justice grounds. Contributing to and capitalizing on a false belief in another, simply for personal (or parochial) gain, would seem to violate the Kantian injunction against treating others as means only. When outright lies are used, it violates one of the most common prohibitions found in deontological theories of ethics, and in most major religions. For the most part settlement-issue deception is done simply for private gain. Only in special circumstances are greater goods, such as innocent lives, at stake.

Deception about settlement issues is also hard to justify on consequentialist grounds. It is costly and inefficient. It can create unnecessary bargaining delays, increase anxiety, and cause lost opportunities as individuals walk away from deals based on the false impression that agreement is not possible. The very prospect of such deception can undermine trust and credibility. The costs may not be easy to identify and may be relatively minor in some individual cases, but they easily get magnified in serious business negotiations, such as collective bargaining. Third parties may be significantly harmed by these practices. ${ }^{5}$ In any case, even 
when the costs are minor, they should not be neglected. ${ }^{6}$ The cumulative effect of this practice may be quite significant. This is not to mention the potential spill-over effects that this deception might have on other aspects of an individual's life. Other than the pleasure that some (by no means all) negotiators get from this element of strategy, it is difficult to see any benefits to off-set these costs.

Finally, we may be concerned about the fairness of the outcome when these sorts of deceptive tactics are used. The final settlement of a negotiation may be largely a function of which party is the best at deceiving the other. Some would not be troubled by this, ${ }^{7}$ but many of us wonder whether this is a fair (or even efficient) way to allocate the gains from trade. It is hard to see how Rawlsian bargainers, behind their veil of ignorance, would embrace this convention. As for real people outside of that veil, there is experimental evidence that, when the gains to each side are known, many individuals refuse even a profitable deal, simply because they deem the division of gains to be unfair. ${ }^{8}$ Furthermore, deception about settlement issues is likely to result in unequal treatment of like cases. For instance, a shrewd bargainer may extract a better salary from her employer than her less shrewd peers. This might be acceptable if shrewd bargaining is part of her job, but if it is not, the result seems unfair.

Despite general moral concerns, the use of these aggressive, deceptive bargaining tactics rarely arouses moral indignation, except in two situations: when there is a special bond of care or trust between the parties (as in a fiduciary relationship or a friendship), and when the party against whom the tactics are used is significantly disadvantaged. ${ }^{9}$ Deception of the former constitutes a breach of trust; deception of the latter violates our sense of fair play and common decency. When the relationship is "arms length" and neither party is particularly disadvantaged, we are rarely inclined to blame the deceiving party. If the deceived party finds out that she has been deceived in this way, she may object, but it is hard to tell whether this objection should be characterized as sour grapes, or whether it constitutes justified moral resentment. In some cases, with experienced negotiators, even the deceived party treats the other party's deception about settlement issues as fair game. Upon discovering that she really could have gotten better terms, her reaction may well be one of regret, possibly self-blame ("how could I have been so stupid?"), rather than one of moral resentment. She may even feel some grudging admiration for the deceiver. Our moral sentiments in practice often do not jibe with the conclusions from our abstract moral reasoning about this practice.

It is interesting to note that the moral toleration for deception about settlement issues is also reflected in the law governing negotiations (torts and contracts) and in the American Bar Association Model Rules of Professional Conduct (the only professional code of ethics that we have seen that explicitly addresses this issue). The law allows recourse against some forms of deception or concealment, but only with regard to "material facts." Settlement issues are not generally taken as material facts. As it is put in comments on Rule 4.1 of the ABA Model Rules, with regard to representing clients in a negotiation with third parties, "Under generally accepted conventions in negotiation, certain types of statements ordinarily are not taken as statements of material fact. Estimates of price or value placed on the subject of the transaction and a party's intention as to an acceptable settlement of a claim are in this category..." (American Bar Association, 1987, p. 185, in the West Publishing edition). Barring the exceptions noted above, this observation seems to capture the spirit of tort and contract law as well. You generally cannot get a judgement against someone for fraud simply because she has deceived you about her true settling point, even if you could prove it.

This special legal treatment for settlement preferences is also a bit of a puzzle. The standard definitions of materiality in tort and contract law seem to turn on "the probability that the fact, if known, would alter the transaction in question. If the ignorant party might have behaved differently had the fact been known, then the fact can be said to be material" (Scheppele, 1988, p. 128). Surely the house buyer, or the defendant's lawyers in the two examples used above would bargain differently if they knew the settlement preferences of the other side. If this is the test, then settlement issues are often material. Why aren't they treated as such?

The puzzle gets deeper when we look at another factor that plays a major role in legal definitions of fraud, namely whether one party has "superior means of knowledge." 10 "Superior means of knowledge" conveys a notion of epistemic advantage. It is not just that the person knows more, it is that she is in a position to know things that the other party would be hard pressed to discover. ${ }^{11}$ A classic illustration of superior means of knowledge is provided by an art dealer who fails to inform a naive seller that the dusty old painting the dealer has just bought from her for $\$ 100$ is a Monet worth a fortune. As Farnsworth points out, "A court is more likely to expect a party to disclose if that party has special knowledge, or a special means of knowledge not generally available to those in the position of the other party" (Farnsworth, 1990, p. 256). This point of common law is conveniently summarized in American Jurisprudence $2 d$, which states:

There is abundant authority to the effect that if one party to a contract or transaction has superior knowledge, or knowledge that is not within the fair and reasonable reach of the other party and which he [the other party] could not discover by the exercise of reasonable diligence, or means of 
knowledge which are not open to both parties alike, he [the first party] is under a legal obligation to speak, and his silence constitutes fraud, especially when the other party relies upon him to judge the expedience of the bargain or transaction. (American Jurisprudence 2d, Fraud and Deceit, section 148)

Again, an individual always has a superior means of knowledge regarding her own (or her client's) settlement preferences. Why do these matters escape the strong disclosure requirement? ${ }^{12}$

One possible answer is that statements about settlement preferences are not statements of fact. The law typically treats opinions, predictions, and statements of intention as different from representations of "objective fact" (Shell, 1990, p. 11-12). The former are often excluded from protection under the law of fraud. Settlement preferences may be characterized as either statements of intention, or as predictions, and, thus, not treated as facts. This is certainly a narrow conception of "fact." It is true that negotiators sometimes do not know their exact settlement preferences, that these preferences change over time, and that they are expressions of conditional intention. However, it is clearly wrong to say that, at any given time, there is no fact of the matter about a negotiator's settlement preferences. Some preferences will be firm and clear, but even when they are not, this is a fact. For an uncertain negotiator to represent herself as having a firm reservation price ("I'll take no less than $\$ 1000$ ") would be to misrepresent the uncertainty of her settlement preferences. These facts may be difficult to establish in a court of law, but that does not make them any less facts. In any case, the fraud law in most states does cover some intentions, under the heading of "promissory fraud" (Shell, 1990, p. 12-13). If some intentions are covered, why not settlement preferences? To assert that these are not "objective facts" is merely verbal sleight of hand. It is not a satisfactory explanation of the special ethical status of deception about settlement preferences.

Some help is suggested by another legal distinction. This is the distinction between intrinsic and extrinsic facts. Intrinsic facts bear directly on the "nature, character, title, safety, use or enjoyment of the subject matter" under negotiation; extrinsic facts have only indirect, "accidental" bearing at best (Story, 1886, section 210, p. 232). Presumably settlement issues are extrinsic matters and, thus, of less concern in the law. However, the boundaries between intrinsic and extrinsic are fuzzy and the distinction has gone out of favor (Scheppele, 1988, p. 129). Nonetheless, it seems to be pointing in the right direction.

We find a related distinction in modern auction theory to be intuitively more appealing and to serve essentially the same purpose. This is the distinction between common-value uncertainty and private-value uncertainty. ${ }^{13}$ Suppose $S$ and $B$ are negotiating the exchange of the property right $X$ from $S$ to $B$. Sharing information that influences the value both bargainers have for an item resolves common-value uncertainty; whereas, sharing $S$ 's knowledge that only affects $S$ 's value of $X$ would resolve $B$ 's private-value uncertainty about $S .{ }^{14}$ Preferences regarding settlement matters typically concern private, rather than common value. However, because some facts that bear on $S$ 's settlement preferences also bear on the common-value of $X$, we will count as pure settlement issues for $S$ only those facts that bear on $S$ 's willingness to settle and her preferences regarding the terms of settlement, that are not also common-value facts about $X$. These facts do not bear on the value of $X$ to $B$ or anyone else other than $S$. This includes not only the traditional notion of $S$ 's reservation price, but also her negotiating aspirations, her resistance to specific concessions, time pressures, and the like.

This analysis suggests a useful matrix for thinking about legal requirements and moral judgments regarding deception and disclosure in negotiation. Assuming that we are talking only about "material" facts, in the sense of facts that if known would matter, the other two dimensions lead to the following categories:

\section{TYPES OF DECEPTION IN NEGOTIATION}

\author{
Material Fact that Bears on: \\ Common Value Private Value
}

Negotiator Has:

Superior Means of Knowledge

No Superior Means

1

2

3
The strongest obligation arises in cell 1, where disclosure is typically required. An example would be a homeowner who knows about a difficult-to-discover termite infestation in a house she is trying to sell. In cell 2 caveat emptor operates to some degree, in that there is no disclosure requirement. Each party must fend for herself in gathering information. Active deception or misrepresentation, on the other hand, is likely to be considered fraud. Think of an antique dealer selling an old chest that has some water damage on one of the legs. The damage is visible to anyone who examines the chest with a little care. With a careless buyer, the 
dealer is not required to point out the damage (though it might be good business to do so). However, if she tries to hide the damage, or makes the assertion that the finish is in perfect shape, she has gone too far. Cell 2 fraud is likely to be rare, given the lack of an epistemic advantage by either party, but it may occur when one party has not done her homework and is naive enough to rely on representations made by the other party. Cell 3 , where settlement issues lie, has no prohibition on either concealment or deception, at least in evenly matched, arms-length transactions. A seller of a house may well assert that she is in no hurry to sell, even though she is desperate.

To draw this matrix does not resolve our puzzle. It simply sharpens the definition. Both common-value and private-value uncertainty create frictions in bargaining due to the possibility of deception. It is easy to understand why deception about common-value facts is treated as more troublesome. With common-value uncertainty, the incentive to deceive can completely destroy all the gains from trade. ${ }^{15}$ With private-value uncertainty, typically only a fraction of the gains from trade are lost as a result of bargaining costs (Cramton, 1984, and Kennan and Wilson, 1989, 1991). This accounts for some difference in treatment, but it does not explain why deception about settlement issues is not objectionable. The question remains: If $S$ 's settlement preferences matter to $B, S$ has a superior means of knowledge about these preferences, and deception about them creates significant bargaining costs (not to mention, violates common moral rules), why do we tolerate, even admire, it in arms-length business negotiations?

\section{Mutual Trust Based Morality}

At this point, we could consider a number of potentially promising answers. No doubt, many readers will already have thought of their favorite candidate. We briefly discuss some other possibilities later. To explore all the possibilities, however, would take us off of our original track. Our stated objective is to examine in some depth one resolution to this puzzle, a resolution that was suggested by conversations we have had with practitioners (executives and lawyers). The resolution points to a general account of morality in practice that has implications beyond this particular issue.

The response that we have heard runs along the following lines. It is generally acknowledged that the practice of settlement-issue deception is less than optimal. In an ideal world, it would be minimized. This justification for engaging in it rests largely on a notion of defensive fair-play in a morally imperfect world. Three conditions seem important in this justification: 1) a unilateral decision to refrain from this deception places one (or one's client) in a vulnerable position, exposed to exploitation by less scrupulous parties, 2) one typically has inadequate grounds for trusting the relevant others to refrain from this sort of deception (in fact, we expect that they will engage in it), and 3) it is unclear that unilateral honesty will have any positive effect, beyond possibly increasing the share of the gains from trade that go to the other, perhaps less scrupulous, party. ${ }^{16}$

These conditions seem to rest on two principles that blend prudence and morality. Together, they characterize the core of the Mutual Trust perspective. We offer the following as a rough cut at formulating them.

Mutual Trust Principle: It is unfair to require an individual to take a significant risk or incur a significant cost out of respect for the interests or moral rights of others, if that individual has no reasonable grounds for trusting that the relevant others will (or would) take the same risk or make the same sacrifice. $^{17}$

Efficacy Principle: It is unfair to require an individual to take a significant risk, or incur a significant cost out of respect for the moral rights of others, if the action that creates the risk or cost is unlikely to have its normally expected beneficial effect, or if it would benefit only those who would not willingly incur the same risk or cost.

These two principles present only part of a comprehensive theory of morality in practice. Each points to a consideration about the specific social context in which actions are taken that can serve, other things being equal, to undermine obligations derived from ideal moral reasoning.

Philosophers will recognize that this argument, particularly the Mutual Trust Principle, has a distinctive Hobbesian flavor. It sounds as if these practitioners view themselves as operating in what Thomas Hobbes called the "state of nature," in which there are no solid grounds for trust.

In such a state, each party is primarily concerned with her own preservation. It is a war of one against all. However, what the practitioners are describing is not a general state of nature, such as the one Hobbes envisioned, (Hobbes, 1651, especially Chapters 13 and 14), but a highly restricted one. They are envisioning a state of nature with regard to this particular aspect of behavior in negotiations. This state of nature, specifically the absence of a basis for trust, provides the justification for defensive, self-interested behavior. 
The requirement of Mutual Trust may be inspired by Hobbes' characterization of the state of nature, but it departs from Hobbes in many of its details. According to the Mutual Trust view, moral society has been incrementally carved out of a state of nature. In the state of nature, individuals have little reason to trust one another. Without trust, there can be only limited cooperation and, consequently, there is little room for putting moral ideals into practice. On the Mutual Trust view, this war of one against all is being held off by constant, sometimes creative, efforts on the part of individuals to "seek peace," to create a basis for mutual trust. ${ }^{18}$ Individuals make truces in the war, by developing negotiating strategies, conventions, norms, legal systems, systems of political power, and religious systems to provide grounds for trusting others, so that they might cooperate with one another to pursue their independent, or commonly held notions of the good life and the good society. Thus, on the Mutual Trust view, taming the state of nature is an incremental, dynamic process. It may never be possible to declare complete victory. One may think of the process historically as starting within families and klans, extending to small, close-knit communities, then developing across different communities, as various forms of interaction and exchange develop. Progress has not been uniform and from time to time there may be a retreat. In Banfield's Montegrano, for instance, little progress is visible beyond moral bonds within the family (Banfield, 1958, especially chapter 5). The progress is not purely geographic or demographic. Even within small, close-knit groups, some types of action (or transaction) remain insecure because of the practical difficulty of creating grounds for mutual trust. Some areas of the state of nature strongly resist taming. We call these pockets of resistance the "moral frontiers." At any place and any point in time, there will be such a frontier. The moral frontier marks the edge of civilized transaction space. Beyond this frontier, one is essentially back in the state of nature.

A major stream of social science research is devoted to understanding the ways in which individuals secure their agreements, act cooperatively, and pursue shared conceptions of the good. In fact, a number of mechanisms that fall short of centralized authority have been identified for pushing back the moral frontier. Potential mechanisms include: reputational strategies (such as tit-for-tat), arrangements that create shared vulnerability, group discussion and multilateral promising, internalization of norms, development of private ethics codes, private institutional arrangements (arbitration systems, Better Business Bureaus, consumer research organizations), and so on. ${ }^{19}$ This is not to say that we fully understand how these mechanisms work, but promising lines of research are underway.

The Mutual Trust view is not committed to a particular account of human nature. However, it presupposes that most human beings are not either pure egoists or pure altruists. ${ }^{20}$ This allows for variety and complexity in human decision-making styles. For present purposes, these styles may be simplified into three categories. ${ }^{21}$ At one extreme there are the opportunists, who are so constituted that they will seek their own fortune with guile, regardless of the behavior of others. The more other people behave morally, the greater the opportunity for the opportunists to take advantage of them. At the other extreme are the moral idealists, who unilaterally behave according to moral ideals, regardless of the behavior of others and the costs to themselves. On the Mutual Trust view few people are solidly in either one of these categories, most are somewhere between the two extremes. Most are pragmatists, concerned with their own material welfare, but also with moral ideals. They are willing and able to constrain their self-seeking behavior for moral reasons, provided that they can be reasonably sure that others with whom they are interacting will do so as well. ${ }^{22}$ Pragmatists are looking for reciprocal moral commitment. They behave like opportunists in the state of nature, not because they are inherently egoistic, but because they cannot trust others to constrain their opportunistic behavior. Pragmatists will gladly do their fair share to create a civil society, but not place themselves at a systematic disadvantage. Notice that all three types, the opportunists and moral idealists as well as the pragmatists, have an incentive to lay a foundation for mutual trust.

In a Mutual Trust world, pragmatists must either be able to avoid the moral frontiers, or they must be psychologically prepared to handle the stress of shifting from one morality to another. The virtues in a morally civilized society are not necessarily virtues in the state of nature. Hobbes took an extreme view of this based on his account of the state of nature as a state of war. In war there is, according to Hobbes a "general rule of Reason, that every man, ought to endeavor Peace, as farre as he has hope of obtaining it; and when he cannot obtain it, that he may seek, and use, all helps, and advantages of Warre" (Hobbes, 1651, p. 190). He explicitly states, "Force, and fraud, are in warre the two Cardinall virtues." (Hobbes, 1651, p. 188). On the Mutual Trust view, this translates into a general obligation to attempt to push back the moral frontiers, when this seems feasible. When it is not feasible to establish grounds for trust and reciprocity, one is entitled to use otherwise immoral practices. This helps to explain why many are inclined to praise shrewd, but deceptive bargaining. When used effectively, it is a virtue on the moral frontier. 


\section{The Mutual Trust Resolution of the Settlement-Issue Puzzle}

As the current norms of negotiation work, it seems clear that, with regard to information about settlement preferences, we are frequently operating along the moral frontier. With regard to the Mutual Trust Principle, (outside of negotiations with close friends, relatives, and associates) we rarely have any assurance that the other party will refrain from attempts at deception regarding settlement preferences. In fact, we usually have general background reasons to believe that the other party will attempt some degree of deception. ${ }^{23}$ To unilaterally refrain from deception in such circumstances would place one at a disadvantage. It would make one vulnerable to exploitation. A foundation of trust has not been created to support the moral ideal of honesty in this case.

With regard to the Efficacy Principle, honesty about settlement preferences is likely to be futile, in that the other party is probably expecting this sort of deception and, accordingly, is not likely to take such claims at face value. Honest disclosures may be misunderstood, or viewed with great skepticism. For instance, if an individual opens the negotiation by proposing a settlement at her reservation price and then refuses to make further concessions, this may be read as unwillingness to negotiate or stubbornness. In one theory of fairness in negotiations, negotiators expect each other to start at their aspirations (the best they could reasonably hope to get) and then seek out a compromise agreement that reflects equal resistance (Maser and Coleman, 1989). Firmness may easily be misread as an insistence on taking an unfair share of the gains. Opportunities may be lost because one is perceived as inflexible.

Furthermore, it is hard to invoke the standard rebuttal about setting an example for others, including those outside of this negotiation, to follow. Because honesty about these matters is especially difficult to demonstrate, few (if any) may ever know that one has been honest in a given negotiation. Without strong evidence, they may presume the opposite. Perhaps some highly visible individuals following a consistent practice over time may develop a reputation for honesty, but this is unlikely for most of us in most of our negotiations. As for other possible benefits from unilateral honesty, we do not have much data on which to base our conclusions. Defensive dishonesty about settlement preferences may cause some moral tension in the pragmatist, but it is unclear whether this tension outweighs the frustration and resentment that naturally accompany being "had" by a less scrupulous negotiator. One may even feel foolish for being unilaterally honest.

The combination of futility, vulnerability, and inadequate grounds for trust characterize a classic moral frontier. Using the Mutual Trust view, we can then see how it is possible to agree that settlement-issue deception is generally an undesirable practice, while condoning it on an individual level. Life in the state of nature has few redeeming features, but once in it one is free to act in a purely self-interested fashion. The Mutual Trust view even explains the fact that we sometimes admire clever deceivers, thinking of them as good negotiators. As noted above, virtues in a state of nature are quite different from virtues in a morally civilized state.

Why have we not tamed this particular portion of nature? The answer seems to lie in the difficulty of reinforcing or securing more honest behavior. It is extremely difficult to create the requisite degree of mutual trust when it comes to settlement issue deception, especially if the negotiating parties have a weak prior relationship and limited opportunities for future exchange. Possible foundations for mutual trust about settlement issues include each party being confident that 1) the other has certain personal characteristics that make her inherently trustworthy, e.g. that the other party is a moral idealist, 2) there is a sufficiently close personal relationship between the parties that a special bond of mutual care has developed, or 3) external control methods are available to detect and punish any transgressions. In many business and legal transactions, conditions 1 and 2 are not readily available, or do not extend to settlement-issue deception. Granovettor (1985) has argued persuasively that economic transactions are embedded in social networks. Nonetheless, these social relations are rarely sufficient to create strong mutual trust. We are often dealing with relative strangers. With relative strangers, trust may need to be anchored in some form of external or institutional controls.

External control methods are weak in the case of settlement-issue deception for two related reasons. Settlement-issue deception is hard to verify in individual cases, and even if it is detected, it would be hard to deliver effective punishment. External control mechanisms depend on reasonably accurate detection of violations. Deception about settlement preferences typically falls into the category of "nonverifiable"24 violations. To say that settlement preferences are typically "non verifiable" in this sense is to say that it would be practically impossible for a third-party to determine with any reasonable degree of confidence what an individual's settlement preferences were at a given point in time. Another way of putting this is that deception about settlement issues is not auditable. 
There are some instances where deception about settlement preferences can be verified. For if the lawyer in our earlier example receives a letter (rather than verbal instructions) from her client stating, 'You may settle at any amount above $\$ 50,000$, but bargain for the highest settlement possible," the contents of the letter are verifiable. However, requiring lawyers to disclose this sort of information in order to detect attempts at deception would be useless. Doing so would serve only to alter the communication between the lawyer and her client. The client would have an incentive to communicate her true preferences secretly to the lawyer and then misrepresent her preferences in any verifiable communication (say demanding at least $\$ 75,000$, rather than $\$ 50,000$ ). Contrast this with a letter from a mechanic that reports that the car frame is cracked as a result of an accident. A key distinction between the mechanic's letter and the client's letter is that the information in the mechanic's letter can be verified, but it is not possible to verify the accuracy of the information in the client's letter.

Of course, we often have reason to suspect settlement-issue deception. In a given case, one may be able to gather some indirect evidence about settlement-issue deception. One could look at similar past transactions by this same party, at the deal the party finally accepts in this transaction, and at future transactions as they occur. Inconsistencies between verbal protestations and actual settlements may indicate some deception. There may even be clues in body language, ${ }^{25}$ but all of this is highly imperfect. People change their minds, change their standards. Circumstances change.

To see the importance of independent verifiability for external control mechanisms, let's consider a few. Individual strategies for promoting cooperation, such as Axelrod's tit-for-tat (1984), work only in special circumstances. Not only is indefinite repeated play required, but each player must know what the other has done on the last play. This is the easiest epistemic hurdle; a negotiator need only satisfy himself that deception is going on. Stilt it is not always possible to get this information. This strategy has hot been effective in conquering settlement-issue deception, because business situations rarely work-out in such a way as to allow a consistent observable pattern of reinforcement to develop. General reputation can also serve to reinforce honesty, but here the epistemic hurdle is a bit higher. $B$ not only has to have reason to believe $S$ is trying to deceive him, but $B$ must be able to demonstrate this to the satisfaction of others with whom $S$ will deal in the future. These others need to be in a position to penalize $S$ for indiscretions with $B$. Third-party adjudication and government enforcement is problematic for the same reasons. Investigations would be costly, and rarely would produce the quality of information needed for action. Because detection would be tare, the punishment would have to be severe to provide an adequate ex ante incentive for honesty. Severe punishment for those unfortunate enough to get caught violates our sense of justice. It is simply too hard to detect and punish transgressions. Consequently, victims of this sort of deception have no legal recourse and private mechanisms (such as insurance and retribution) are rarely available. Until a mechanism is available that reasonably assures reciprocity, the Mutual Trust view of morality in practice would say that it is ethical to engage in the practice for defensive reasons.

\section{Alternative Accounts of Settlement Deception}

The Mutual Trust account is not the only possible resolution of the puzzle regarding settlement-issue deception. In this section, we consider four alternative rationales for engaging in settlement-issue deception. Each has appeal and accounts for some cases. However, even taken together, they cannot account for the widespread and purposeful use of deception in negotiation that is captured by the Mutual Trust account.

\section{It's Only a Game}

Following Carr's (1968) famous suggestion, it can be claimed that negotiation is a game like poker. It has its own rules, and the rules allow for settlement-issue deception. Anyone who has chosen to play is free to engage in any tactic that is permitted by the rules.

What is it about the game analogy that gives this argument its moral force? Surely not all games are morally acceptable. Two people could invent a game of throwing knives out of a tenth floor window onto a busy street. The rules may permit, even encourage, intentionally trying to hit pedestrians, but this does not justify throwing knives at pedestrians. People who use the game argument must have in mind certain morally relevant features of recreational games. Several features of recreational games seem morally relevant: such games are harmless to those who choose not to play, probable harm to the players is also limited, the rules are clear to all, entry to and exit from the game are fully voluntary, the players are relatively evenly matched (or given appropriate handicaps), and they freely consent to the rules (and to the limited harm that might be done 
them). ${ }^{26}$ As some of these features are absent from games, moral questions can arise about whether and how one should play.

One source of appeal for this line of argument is that some practitioners do use the language of games to describe negotiation. Even the ABA Model Rules seem to rest the case for settlement-issue deception on nothing deeper than the "generally accepted conventions of negotiation." Furthermore; some negotiations are indeed very much like harmless parlor games. A prime example is bargaining over some souvenir in a bazaar. In such a case, strategic posturing, haggling, threatening to walk away from the deal, and bluffing are an important part of the fun. The availability of deceptive tactics is well known and often adds to the utility of the negotiators. It creates suspense, intrigue, and challenge. No one seems to be seriously harmed in the process. People who engage in this recreational negotiation typically know what they are getting into and freely choose to take the modest risks associated with it.

The difficulty is that many common business and legal negotiations lack the essential morally relevant features of recreational games. Think of labor negotiations, strategic arms reduction talks, the purchase of a car or a house, an accident settlement, plea bargaining, or initial contract negotiations with a major business supplier. Even if the negotiators in these situations are aware that settlement-issue deception is a common practice, and so expect it, it is stretching the truth to say that they somehow consent to a clear set of rules allowing it. Acquiescence is not the same as free consent. The absence of alternative institutional arrangements for coming to agreements on these matters raises questions about how fully voluntary the decision is to enter (and not to exit) from this sort of negotiating context. For most negotiators in these settings, the prevalence of settlement-issue deception is not a desirable feature of the negotiation "game." They are not looking for recreation, suspense, and intrigue. Regretfully accepting that deception is the norm does not carry the same moral weight as welcoming a rule because it makes the game more fun. The stakes are often significant and in many cases there are externalities. Third parties, who had no choice, may be affected. Think of small communities that are affected by labor negotiations with the community's major employer. The game analogy underestimates the morally problematic features of settlement-issue deception in a wide range of cases. It has a very limited range of application.

\section{No Real Deception}

People expect others to engage in some deception about settlement issues. One might argue then that no one is really deceived. They may guess wrong in a given case, but no one takes seriously the posturing and claims of the other negotiator regarding settlement issues. Experienced negotiators discount the claims of others to reflect this practice. ${ }^{27}$

Of course, that something is expected does not justify it, but the argument here is a bit more subtle. The claim is that, in effect, there is no deception. This is true only if the parties are fully rational and completely understand the situation they are in. Real negotiators rarely fall into this category. Even if they have unlimited abilities to calculate, they probably do not have the base of common knowledge that is needed to anticipate all deceptions. To guarantee that deception does not occur it must be that the negotiating strategies of all the parties are common knowledge. This may be a reasonable assumption in rudimentary games, where rationality leads to a unique prediction of behavior. But even the simplest negotiations are fraught with multiple equilibria when private information is introduced (Ausubel and Deneckere, 1989). We must acknowledge that expecting deception is not sufficient to prevent it, or to fully mitigate its effects.

Sometimes people are deceived about settlement issues because they are naive or gullible. Even a sophisticated negotiator can be deceived in a given case. What they know is that the other party may be attempting to deceive them. In any given case, negotiators face much uncertainty and have little information about the precise form any deception might take. The problem is that sometimes people attempt to deceive negotiation partners, and sometimes they do not. Truly clever negotiators will use this uncertainty to their advantage, overcoming the other party's skepticism, or using that skepticism to their advantage. Poker provides an example of a setting where the rules of the game are common knowledge and yet deception still frequently occurs. In poker, we expect people to bluff sometimes. With a good player, it is hard to tell when she is and when she is not. The expectation of bluffing does not prevent successfully using bluffing strategies. The strategies simply become more sophisticated. That is what makes poker interesting. Often the best gains come when you do have a strong hand, but you get others to believe you are bluffing. They stay in the game, calling, perhaps even raising your bets, creating a large pot. You bluff (perhaps even get caught), not so much to fool people about the quality of your hand, but to gain a reputation as someone who does bluff. That reputation allows you to confuse and mislead opponents in other hands. Skilled players are probably deceived less than beginners, but even a skilled player's expectations are not always consistent with the facts. 
Even if we are willing to grant that the negotiators are fully rational, that they understand the "rules of the game," and that their negotiating strategies are common knowledge (so that, in a sense, deception does not occur), this does not imply that attempts at deception do not cause problems. Indeed, the inefficiencies caused by the option to deceive may well be greater when the parties rationally mistrust each other. The parties will have to take costly actions, such as risking impasse or delaying trade, in order to make claims credible.

We can easily imagine a negotiation in which the offers and counteroffers, threats, and promises are all choreographed. The two negotiators know each other well. They know where the settlement will be from the beginning. The negotiation is just a ritual. Neither takes the other's posturing seriously. In such a case, we should grant that there is no deception, but such cases are relatively rare. This argument does not dissolve the puzzle about widespread settlement-issue deception.

\section{No Intentional Deception}

Another tack would be to acknowledge that deception does occur, but claim that it is only an unintended, but necessary side-effect of the natural process of signaling and learning that characterizes negotiation. When a person approaches a negotiation, that person typically does not know whether a deal is possible and on what terms. A negotiator's initial settlement preferences are conditional and open to revision as she gains a better understanding of the settlement preferences of the other party. Because straight-forward revelations of settlement preferences are problematic, the only reasonable way to elicit credible information from the other side is to make proposals or to send behavioral signals designed to find out where the other party stands on key issues. This often requires making proposals or conveying impressions that do not reflect one's actual settlement preferences at the time. The art of negotiation lies in eliciting information and signalling just enough about one's own position to efficiently determine whether a bargain is possible and, if so, to find a fair and reasonable settlement. If someone is deceived by ploys to elicit information, that is unfortunate, but given the complexities of gathering credible information in this context, it cannot be helped.

No one can deny that many maneuvers in a negotiation are attempts to gather information about the other side. The question is whether these attempts are simply innocent information eliciting devices, or whether they are at the same time deliberate attempts at deception. The answer probably varies from one negotiation to another. The negotiator's objective in making a proposal that misrepresents her settlement preferences may be to find out as much as possible about the preferences of the other side, while at the same time confusing or misleading the other side about her own settlement preferences. This strategy of trying to learn while preventing the other party from learning can (if successful) generate the best outcome in many negotiations, and it reflects the spirit of White's comment quoted earlier to the effect that misleading one's opponent is the essence of negotiation. In any case, this argument is largely compatible with the Mutual Trust account. Clever maneuvering is required to produce credible information from the other side just because trust is absent and verification is inherently difficult. The difference lies in the hypothesis about intentional deception. While it may be true that some negotiators are innocent information gatherers and signalers, content to achieve a settlement based on relatively equal information, our experience suggests that many are deliberately engaging in deception while they are gathering information. In such cases, the Mutual Trust perspective does a better job of accounting for the negotiators' behavior.

\section{Right Not to Disclose}

On this view, information about settlement preferences should be revealed only at the discretion of the party involved. $B$ has no right to know $A$ 's settlement preferences, or the facts bearing only on those preferences. A may choose to disclose her eagerness to conclude a deal, or may reveal her real bottom line in hopes of saving time and fuss, forgoing the opportunity to strike a better deal. However, it would be wrong to require such disclosure. ${ }^{28}$ It might be inappropriate to let settlement preferences determine the final terms of agreement. In many cases, we would like more objective factors to prevail in determining a fair settlement. Think of an academic whose spouse strongly prefers to be in a given city for career reasons. The academic finds only one suitable opening at a local college, and would accept the job at a substantial reduction in pay from the going rate at that school. Should she be required to reveal these family circumstances, and perhaps be offered a lower salary as a result? Should the school be permitted to take advantage of her situation? Many would say not. $^{29}$

This argument is especially strong when one party is particularly desperate. To reveal the information about reservation price, aspirations, values, and so on, should be optional. In such a case, revelation creates a risk of exploitation. It creates vulnerability, even when the other (less desperate) party is willing to disclose 
settlement preferences. The case is strengthened when the vulnerable party is in a class that has suffered economic discrimination. This line of argument also has some appeal, for different reasons, when one party has invested time and money in gathering information and the other party has not invested similar time and money. ${ }^{30}$ If the investment has enabled the discovery of an attractive opportunity, it would seem inappropriate to require the party who made this discovery to disclose settlement preferences that are informed by this discovery. By revealing these settlement preferences, the investor might not be able to profit from, or even recoup the investment. Required disclosure would have the perverse effect of discouraging investment in the search for information.

We do not see this argument as a direct competitor to the Mutual Trust account of settlement issue deception. It does not answer the same question. It accounts for settlement-issue concealment, not settlementissue deception. Presumably, deception would be permitted only as a last resort to protect private information, when releasing this information would have harmful effects. This argument may account for some settlementissue deception, but it certainly does not explain the extensive settle-issue deception that we observe in practice. At its heart, this argument seems to rest on some of the same concerns that motivate the

Mutual Trust view, namely the vulnerability created by candor in these competitive settings and the risk of being treated unfairly. The best way to understand this argument is as a supplement to the Mutual Trust account. It says that even if we could tame this part of the state of nature, we would still not want to require disclosure of settlement preferences in all cases. Mutual sharing of information about settlement preferences might generally be a good thing, but in some cases it would not be so good for all parties. Some vulnerability to exploitation will remain. In the absence of protective mechanisms, concealment (perhaps even deception) in such cases is morally justified.

\section{Concluding Comments}

We have considered a number of competing justifications for settlement-issue deception, each with a certain amount of validity. None of these accounts seems to capture the wide range of cases that could be explained by the hypothesis that a significant number of people, particularly lawyers and business people in this country, accept something like the Mutual Trust perspective on morality in practice that we have presented in this paper. This perspective has been openly endorsed by some practitioners. As an explanation for the puzzle about settlement-issue deception, it allows us to account for moral regret about the general practice of settlement-issue deception, while at the same time seeing how it might be justified, even admired, in practice. It also helps to explain why some business people see the law as providing a reasonable moral baseline. The law (if effectively enforced) can be instrumental, in the absence of more personal influences, in creating a basis for trust. The Mutual Trust account also helps explain the queer coincidence between the ease of detecting a given form of deception and our sense of moral outrage about it. Actual lies are regarded by many as inherently more objectionable than more subtle forms of deception, and deception about easily verified matters of fact is more objectionable than deception about more private matters. Trust is better established where detection is relatively easy.

\section{Risks Inherent in the Mutual Trust Perspective}

The Mutual Trust view clearly has its drawbacks. We would be remiss if we did not at least briefly discuss the potential problems. Most importantly, this may be a dangerous perspective to promote. A world of Mutual Trust pragmatists may be better than a world of selfish opportunists, but it is also a world fraught with moral problems. If a sufficient number of these pragmatists are risk averse, meaning that they have low risk and cost thresholds at which they invoke the Mutual Trust Principle, and that they initially distrust others until provided with grounds for doing otherwise, the problems of establishing and maintaining moral norms are likely to be severe. The problems are worse still when the boundaries at the moral frontiers are not clear. A mistake in judgment about whether or not grounds for trust are present can be quite costly to the individual involved and to others who are confused by this individual's behavior. It poses the prospect of moral regression. Trust may be eroded; downward spirals of more and more morally offensive behavior may occur. Only two forces work against this self-destruction of the Mutual Trust world, the commitment of the moral idealists to maintain high standards regardless, and the natural desire of individuals to "seek peace," as Hobbes would put it.

To the extent that we are faced with a world largely consisting of moral pragmatists and containing many pockets of distrust, it may even seem irresponsible to urge individual professionals to sacrifice personal and 
client interests for moral ideals. Rather, it may be more reasonable to place our emphasis on convincing them to integrate into their Mutual Trust perspective a third principle, that runs as follows:

Trust Building Principle: When mutual trust is absent or weak, individuals should be willing to take modest risks or incur modest costs, in an effort to build or reinforce the trust required to secure moral action in the future.

Of course, this principle will be appealing to pragmatists only if its demands are moderate and it is reasonable to believe that other pragmatists will commit to building trust. Fortunately, the benefits to be had from cooperative endeavors to improve on the state of nature are too great for most to ignore. They provide the impetus for peace-making experiments, for investments, for risk-taking in hopes of reducing the undesirable features of the moral frontier. Nonetheless, even if the Mutual Trust view is supplemented with a Trust Building Principle, a given amount of moral tension and confusion is inevitably created as people switch from the state of nature to more civilized transaction space, from one set of standards to another. This is likely to create spill-over effects. These effects are the regrettable by-products of living in a morally imperfect world.

The Mutual Trust perspective is limited in what it justifies. It does not justify shrewd bargaining with parties known to be innocent or naive. Their very naivete provides a basis for trust. There can be some sense of decency even at the moral frontier. It also fails to justify shrewd bargaining in some special trusting relationships. And it does not justify escalation of the "war" beyond the edges of the moral frontier. In general, this perspective provides only a tentative and pragmatic justification for individual instances of deception, not a blanket justification of the practice. Nonetheless, there is a risk that the Mutual Trust line of argument will be abused, sloppily applied, or consciously misused to purportedly justify genuinely objectionable behavior. Opportunists may be happy to masquerade as pragmatists. We must encourage a critical approach.

Our point in this paper is not to promote moral pragmatism and its accompanying Mutual Trust perspective, but to recognize it as a feature of morality as it appears in practice. Those of us dedicated to understanding and enhancing professional ethics need to reckon with this perspective. We need to be fully aware of its features and its dangers. We also need to respond to it in a way that is likely to be effective in practice. Moral exhortation and abstract moral reasoning have their place, but they also have their limits.

\section{Implicarions for Practitioners}

In hopes of bringing practice closer to moral ideals, we could urge everyone to become moral idealists, carrying their ethical principles beyond the moral frontiers, indifferent to personal risk and cost. However, this would require imparting a high level of generalized benevolence, or moral commitment, higher than it seems reasonable to expect outside of particularly strong religious or moral communities. Until we can agree on an acceptable and effective program for doing this, it seems safe to remain skeptical about it. Without a more practical orientation, morally idealistic proposals are likely to be dismissed out of hand. What makes more sense is to urge people to exercise due care in assessing any negotiation situation and, especially where the social stakes are high, to experiment with methods for pushing back the frontier.

A separate paper is required to fully explore the issues and strategic options for practitioners. These would include guides for recognizing when one is at the moral frontier, methods for reducing the personal risks or costs of living up to moral ideals, possible avenues for creating trust, and techniques for minimizing the external costs of operating at the moral frontier. Here we can only sketch some of the general implications for negotiators.

In assessing whether there are sufficient grounds for trust, a negotiator should consider a number of factors concerning the basis of her relationship with the other party and the other party's incentives. Longterm relationships, empathy based on familiarity or common background, and common networks of relationships provide reasons for believing that trust is present. Trust is less likely to be present in one-shot negotiations with a relative stranger in which the stranger stands to gain a significant amount, or in adversarial negotiations where there is a history of mistrust or hostility.

If trust is absent and the transaction is large enough to justify the cost, trust may be built or reinforced through a variety of mechanisms. Because of verifiability problems, these mechanisms must not rely on independent access to the other party's settlement preferences. Potentially viable mechanisms fall into three categories, those that create opportunities to demonstrate trustworthy behavior, those that rely on external incentives, and those that attempt to create internal incentives. If the negotiation can be broken down into stages, the early stages may be structured so that the parties can each take some risks and demonstrate trustworthiness on issues that involve relatively low stakes. In one-shot transactions, reputations can be 
introduced by requiring each party to the transaction to provide a list of those they have dealt with recently. Honesty can also be motivated by external incentives, provided that arrangements can be made with a third party to pay a bonus, exact a penalty, or make an appraisal (Brains, 1990, Chapter 2). But for these procedures to work, strong assumptions about rationality and a base of common knowledge are required. Moreover, these procedures often do not avoid the inefficiencies created by the option to deceive. The internal mechanisms represent attempts to influence the preferences of the other party, making the other party more empathetic, more directly concerned not to take advantage. These are attempts to create mutual local benevolence, rather than relying on a more generalized benevolence. Mechanisms for doing this usually involve more frequent communications or more informal contact (increasing familiarity).

The best hope for building trust about settlement-issue deception among strangers or adversaries seems to lie not in standard external control mechanisms, but in relationship building and development of notions of group identity. Sometimes all that is needed is for the parties to get together on a regular basis to share concerns and other information relevant to an upcoming negotiation. ${ }^{31}$ Some recent work on social dilemmas suggests that discussion and the creation of a sense of group identity can be a powerful tool in creating, at least in-group, trust (Dawes, 1990, and Orbell, Dawes, and van de Kragt, 1990). Negotiators should make reasonable efforts toward establishing an environment of trust and cooperation. We clearly need creative experimentation to find solutions to this problem. That creative solutions are often difficult to discover, does not justify the immediate use of cutthroat deceptive tactics, even on the Mutual Trust view.

All this said, in many cases of settlement-issue deception where the practice is widespread and the deception is hard to detect even ex post, trust building may not be viable. In many cases of negotiation, especially where the stakes are relatively small, caveat emptor may be the best advice.

\section{Next Steps}

Many questions remain about the Mutual Trust perspective. The theory clearly needs to be fleshed-out in more detail. Empirical work is needed to provide a better understanding of how this perspective is reflected in practical decision making. We need to find out whether people actually think and act like moral pragmatists, as we characterize them. Are people willing to take risks or make genuine sacrifices when trust is present, that they would not make in the absence of trust? We also need to develop and refine the principles that constitute the Mutual Trust perspective. How do pragmatists think about appropriate thresholds of risk and cost? What sorts of risks and costs will they endure for the moral ideal of honesty, or for other moral ideals? How do they determine the "relevant others" in applying the Mutual Trust Principle? Are the relevant others always defined simply as direct competitors or adversaries? What about customers who may be affected by deceptive advertising, or rape victims who may be harmed by aggressive, harassing cross-examination? How do pragmatists determine whether sufficient trust is present in a given situation? How do they assess the efficacy of unilateral moral action? What are the other plausible candidates for moral frontiers, beyond settlementissue deception? Are there moral frontiers that people have no desire to push back, that they wish to leave untamed? The reader could easily extend this list. However, in addition to descriptive questions, we also need to do some practical prescriptive research.

If the Mutual Trust account is a reasonable reconstruction of a view widely held, perhaps the most useful research that we can do for practitioners is research that helps them find strategies for bringing practice closer to moral ideals. We can share success stories, and provide problem-solving frameworks. This suggests that the most important work in business and legal ethics may not be the construction of arguments to appeal to moral idealists, but the creation of actionable strategies for the pragmatists. We may need to shift resources and energy from the construction of arguments to the effect that "It would be best if everyone did $A$," to concrete proposals for creating climates of trust in which our moral ideals might stand some hope of being implemented. This presents a challenge to philosophers to build closer ties to other disciplines and to actual practices, so that they might better address ethical concerns from a practical point of view.

Harvard Business School and the Yale School of Management 
* We are grateful to Warren Schwartz for urging us to look more closely at settlement-issue deception, and to Kenneth Andrews, Steven Brams, Frances Kamm, Susan Koniak, Lynn Paine, Seana Schiffrin, Howard Stevenson, Dennis Thompson, along with participants in the New York University Ethics Colloquium for their comments on earlier drafts.

${ }^{1}$ The tales were originally written by Joel Chandler Harris in his Uncle Remus stories. This modern language version has been adapted (with slight alterations) from Bellow and Moulton, 1981.

${ }^{2}$ Someone holding the Mutual Trust view might construct her moral ideals using nearly any kind of moral theory. She simply questions the logical step in the deontological argument that moves from "It would be good if everyone in like circumstances did $A$ " to "I should do $A$ even though others similarly situated are not doing, or would do $A$." The parallel in the utilitarian argument would be to challenge the step from " $A$ creates the greatest good for all, counting myself no more than anyone else" to "I should do $A$ even though others are ignoring or would ignore my utility in making similar decisions."

${ }^{3}$ Kavka (1983) presents a view similar to the Mutual Trust perspective in his treatment of defensive violations of moral rules, and Bok (1978) also looks at similar defenses in her treatment of lying, but we believe that neither gives adequate expression to, nor captures the appeal of the full Mutual Trust perspective.

${ }^{4}$ We will use the word deception narrowly to cover cases of deliberate actions taken, or statements made with the intention of creating or helping to perpetuate a false belief in another party. Common usage may allow for unintentional deception, but we are concerned only with the deliberate variety. For detailed treatment of some of the definitional complexities regarding deception and lying see Chisholm and Feeham (1977) and Fried (1978).

${ }^{5}$ See the discussion of externalities in Lax and Sebenius (1986), pp. 152-53.

${ }^{6}$ For a discussion of the complexities of consequentialist analysis when the harm from an individual action is not so readily visible or significant, see Parfit (1984), Chapter 3, pp. 67-86.

${ }^{7}$ Libertarians would probably not see this as troubling. See, for instance, Nozick (1974), Chapter 7, pp. 149-82, for a theory of just transfer that does not concern itself with the distribution of gains.

${ }_{8}^{8}$ Güth, Schmittberger, and Schwarze (1982) conducted an experiment where one bargainer makes a single take-it-or-leave-it offer to another. They find that if the offeror demands much over $50 \%$ of the gains from trade, the other tends to reject the offer and the gains are lost. This behavior suggests that bargainers have a preference for fairness. Kahneman, Knetsch, and Thaler (1986) also find that individuals will reject divisions that they regard as too lopsided, even if the rejection means that they get nothing. This preference for fairness is also found when the subjects can make many offers but delay is costly (Ochs and Roth, 1989).

${ }^{9}$ For a discussion of fiduciary and confidential relationships in the law see Scheppele (1988), pp. 138-51 and pp. 171-75. On the topic of disadvantage and considerations of distributive justice, see Kronman (1980) and Lax and Sebenius (1986), pp. 15052.

${ }^{10}$ For a discussion of the role this factor plays in the law of fraud, see Scheppele (1988), pp. 134-60. We follow Scheppele's analysis throughout this discussion of the relevant law.

${ }^{11}$ This distinction is more complex than it might first appear. The complexity is apparent when we consider the sticky issues raised by individual investment in superior knowledge. If one party makes a significant investment in gaining knowledge that allows her to identify a great opportunity, should she not have the right to use that knowledge for gain? To require disclosure of all superior knowledge would undermine any incentive to do one's homework. This suggests that we will want to be careful in distinguishing between superior means of knowledge (which presumably allows one access to superior information at low or no cost), and superior knowledge gained the hard way.

${ }^{12}$ One possible explanation of the different treatment given to settlement preferences is that there is a certain symmetry. Each party has superior means of knowing her own settlement preferences. However, it is hard to see why symmetry should matter for these issues because it clearly does not matter for other material considerations. If both parties have superior means of knowledge regarding other important aspects of the item under negotiation, then presumably both have an obligation to disclose. The two obligations do not cancel each other out.

${ }^{13}$ Note that this distinction is quite different from the distinction between creating common value and creating private value that is discussed by Lax and Sebenius (1986), pp. 88-116.

${ }^{14}$ We do not claim that this distinction is perfectly clean. Some facts may predominantly affect S's value, only slightly bearing on $B$ 's value. In this case, it may seem inappropriate to classify it as a common-value fact. However, in many circumstances, we can sensibly distinguish between common and private value.

${ }^{15}$ As an example, suppose $S$ 's value of $X$ is $v$ and $B$ 's value is $1.5 \mathrm{v} . S$ knows the true value $v$, but $B$ only knows that $v$ is uniformly distributed from 0 to 1 . In this case, despite the fact that gains from trade surely exist, if both $S$ and $B$ are rational and $S$ cannot be trusted to honestly report v, then $B$ will be unwilling to trade with $S$ (Akerlof, 1970 and Samuelson, 1984). If $B$ offered $S$ a price of $p$, then $S$ accepts if $v \leq p$, so $B$ 's expected gain given acceptance by $S$ is $E(v \mid v \leq p)-p=1.5(p / 2)-p=-$ $p / 4$. Thus, any offer $B$ makes results in a loss; $B$ 's best response is not to deal with $S$.

${ }^{16}$ This argument should not be confused with the argument that because it is common practice, it is morally acceptable to go along with it. The argument presented is more specific and narrow in its claims. It should also be distinguished from most of the arguments that Bok (1978) rebuts in her chapters on lying to liars and enemies (pp. 130-53). It is not about revenge. The other may have done no wrong.

${ }^{17}$ This principle resembles Elster's "norm of fairness." "The norm of fairness tells an individual to cooperate if and only if everybody else, or at least a substantial number of others, cooperate" (Elster, 1989, p. 187). While both appeal to the same notion of fair play, they are logically distinct. In content, the Mutual Trust Principle is concerned with moral behavior. Morality cannot always be reduced to a form of cooperation. Think of the original prisoners' dilemma example. The cooperative response is for two guilty prisoners to refuse to tell on each other. This is surely not the moral, or socially preferred response. On many occasions in law and business, the moral (and the risky) thing is to compete when others would prefer you to cooperate (collude) 
for mutual gain, at the expense of some third party. In form, the Mutual Trust Principle is not posed as an "if and only if" decision rule. This principle provides only one consideration among many to be weighed in the final decision.

${ }^{18}$ The Mutual Trust view, as we characterize it, rejects Hobbes' view that an all-powerful political ruler (a Leviathan) is required to provide grounds for moral constraint on self-seeking behavior. Perfect assurance of compliance is not necessary, only reasonable assurance is required, and this can be achieved incrementally through a variety of individual and social arrangements that fall far short of a Leviathan.

${ }^{19}$ For a sampling of this literature, see Axelrod (1984), Kreps (1990), and Wilson (1989) on reputational strategies, Kronman (1985) on forms of mutual vulnerability (such as collateral, hostage taking, and hands-tying), Orbell, Dawes, and van de Kragt (1990) and Dawes (1990) on forms of multilateral promising and group discussion, and Arrow (1973) on ethics codes. Hirschleifer (1982) provides a wide ranging discussion of the evolution of norms in groups. Taylor (1982) makes a case for the importance of small close-knit communities for non-political, non-coercive mechanisms to work. Zucker (1986) provides an account of various mechanisms of trust formation in an economic setting. Coleman (1990) presents a comprehensive theory of the way authority, trust, and norms develop among individuals and organizations.

${ }^{20}$ Hobbes, by contrast, is typically characterized as assuming that humans are by nature egoistic, personal utility maximizers. For an extensive discussion of both psychological and moral egoism in Hobbes, see Kavka (1986), Chapters 2 and 9. Kavka indicates the uncertainty and complexity of Hobbes' views on human nature and on morality.

${ }^{21}$ A similar tripartite distinction has been made by Peter Koslowski in a talk on "Private Vices, No Public Virtues," at the Harvard Kennedy School of Government, February 26, 1990. These three types are clearly constructed as ideal-types. Real people are probably more complex than any one of these characterizations, being moral idealists on some things, pragmatists about other things, and opportunists about still others.

${ }^{22}$ Our pragmatist is quite similar to Gauthier's "constrained maximizer." See his (1986) chapter 6, pp. 157-89. However, our characterization is intended to be broader, less dependent on any specific theory of morality, such as Gauthier's bargainingbased conception.

${ }^{23}$ The degree of deception is moderated by self-interest. As long as there is an incentive to reach a settlement and to do so in a timely fashion, individual negotiators will moderate their deceptive maneuvers.

${ }^{24}$ By "verifiable" we do not mean the "in principle verifiability" of the logical positivists, but verifiability in the sense of credible independent verification.

${ }^{25}$ See Ekman (1985). The implications of this way of imperfectly detecting dishonesty are discussed by Frank (1987).

${ }^{26}$ For a discussion of these first two features and some general ethical tests regarding negotiation tactics see, Lax and Sebenius (1986), pp. 147-5O.

${ }^{27}$ This sort of argument is similar to the argument for permitting puffery in advertising.

${ }^{28}$ This argument might be founded on the notion that settlement preferences are private matters, the personal property of their bearer. A similar argument regarding the privacy of ideas is presented in Paine (1990). However, it need not rest on the personal nature of these preferences. It might be founded on a desire to protect disadvantaged negotiators from exploitation, or socially undesirable discrimination.

${ }^{29}$ This example and some of the language in framing this argument are due to Frances Kamm.

${ }^{30}$ In keeping with the matrix presented earlier in the paper, we are assuming that this common-value information was available to both parties. Neither had a superior means, or special access to the information.

${ }^{31}$ This practice has been used successfully in recent union contract negotiations. Labor contracts between CBS and IBEW now write into the contract that the parties "shall meet at least once every three months, unless waived by mutual consent, to discuss subjects of mutual concern or interest that may arise during the term of this Agreement or matters necessary to the implementation of this Agreement."

\section{Bibliography}

Akerlof, George A.: 1970, 'The Market for 'Lemons': Quality Uncertainty and the Market Mechanism." Quarterly Journal of Economics 84, 488-500.

American Bar Association Model Rules of Professional Conduct.: 1987, Selected Statutes, Rules and Standards on the Legal Profession (West Publishing, St. Paul).

American Jurisprudence 2d.: 1968, Vol. 37, Fraud and Deceit (The Lawyers Co-operative Publishing Company, San Francisco).

Arrow, Kenneth J.: 1973, "Social Responsibility and Economic Efficiency." Public Policy, 21, 303-17.

Ausubel, Lawrence M., and Deneckere, Raymond J.: 1989, "A Direct Mechanism Characterization of Sequential Bargaining with One-Sided Incomplete Information," Journal of Economic Theory, 48, 18-46.

Axelrod, Robert.: 1984, The Evolution of Cooperation (Basic Books, New York).

Baier, Annette.: 1985, "Doing Without Moral Theory?" Postures of the Mind: Essays on Mind and Morals (Methuen, London).

Banfield, Edward C.: 1958, The Moral Basis of a Backward Society (The Free Press, New York).

Bellow, Gary, and Moulton, Bea.: 1981, The Lawyering Process: Negotiation (Foundation Press, New York). Bok, Sissela.: 1978, Lying: Moral Choice in Public and Private Life (Random House, New York). 
Brams, Steven J.: 1990, Negotiation Games: Applying Game Theory to Bargaining and Arbitration (Routledge, New York).

Carr, Albert Z.: 1968, “Is Business Bluffing Ethical?” Harvard Business Review. January-February, 1968, 143-153.

Chisholm, Roderick, and Feehan, Thomas D.: 1977, “The Intent to Deceive,” Journal of Philosophy 74, 14359.

Coleman, James S.: 1990, Foundations of Social Theory (Harvard University Press, Cambridge, MA).

Cramton, Peter C.: 1984, "Bargaining with Incomplete Information: An Infinite-Horizon Model with TwoSided Uncertainty." Review of Economic Studies 51, 579-593.

Dawes, Robyn M.: 1990, "Social Dilemmas, Economic Self-Interest, and Evolutionary Theory." Forthcoming in Research in Psychology: Frontiers of Mathematics, Essays in Honor of Clyde Coombs (SpringerVerlag, New York).

Ekman, Paul.: 1985, Telling Lies (W. W. Norton and Company, New York).

Elster, Jon.: 1989, The Cement of Society: A Study of Social Order (Cambridge University Press, New York).

Farnsworth, Allan.: 1990, Contracts (Little, Brown, and Co., Boston).

Frank, Robert H.: 1987, "If Homo Economicus Could Chose His Own Utility Function, Would He Want One with a Conscience?" American Economic Review, 77, 593-604.

Fried, Charles.: 1978, Right and Wrong (Harvard University Press, Cambridge, MA).

Gauthier, David.: 1986, Morals By Agreement (Clarendon Press, Oxford).

Granovettor, Mark.: 1985, "Economic Action and Social Structure: The Problem of Embeddedness." American Journal of Sociology, 91, 451-510.

Güth, W., Schmittberger, R., and Schwarze, B.: 1982, “An Experimental Analysis Ultimatum Bargaining," Journal of Economic Behavior and Organization, 3, 367-88.

Hirschleifer, Jack.: 1982, "Evolutionary Models in Economics and Law: Cooperation versus Conflict Strategies." In P. H. Rubin and R. O. Zerbe, Jr. eds., Research in Law and Economics 4, 1-60, (JAI Press, Greenwich).

Hobbes, Thomas. 1651. Leviathan. All references are to the C. B. Macpherson edition, 1968, (Penguin Books, Baltimore).

Kahneman, Daniel, Knetsch, Jack L., and Thaler, Richard H.: 1986, "Fairness and the Assumptions of Economics," Journal of Business, 59, S285-S300.

Kavka, Gregory S.: 1983, “When Two 'Wrongs' Make a Right: An Essay on Business Ethics.” Journal of Business Ethics, 2, 61-66.

Kavka, Gregory S.: 1986, Hobbesian Moral and Political Theory (Princeton University Press, Princeton).

Kennan, John, and Robert Wilson.: 1989, "Strategic Bargaining Models and Interpretation of Strike Data," Journal of Applied Econometrics, 4, S87-S130.

Kennan, John, and Robert Wilson.: 1991, "Bargaining with Private Information," Journal of Economic Literature, forthcoming.

Kreps, David M.: 1990, “Corporate Culture and Economic Theory.” In James Alt and Kenneth Shepsle (ed.), Perspectives on Positive Political Economy (Cambridge University Press, New York).

Kronman, Anthony T.: 1980, “Contract Law and Distributive Justice," The Yale Law Journal 89, $472-511$.

Kronman, Anthony 1:: 1985, "Contract Law and the State of Nature," Journal of Law, Economics, and Organization 1, 5-32.

Lax, David A. and Sebenius, lames B.: 1986, The Manager as Negotiator (The Free Press, New York).

Maser, Steven M. and Coleman, Jules L.: 1989, "A Bargaining Theory Approach to Default Provisions and Disclosure Rules in Contract Law," Harvard Journal of Law and Public Policy, 12, 637-709.

Nozick, Robert.: 1974, Anarchy, State, and Utopia (Basic Books, New York).

Ochs, lack, and Roth, Alvin E.: 1989, "An Experimental Study of Sequential Bargaining," American Economic Review, 89, 355-384.

Orbell, John, Dawes, Robyn, and van de Kragt, Alphons.: 1990, "The Limits of Multilateral Promising." Ethics, 100, 616-627.

Paine, Lynn.: 1990, "Trade Secrets and the Justification of Intellectual Property: A Comment on Hettinger." Mimeo.

Parfit, Derek.: 1984, Reasons and Persons (Oxford University Press, New York). Page references are to the 1985 corrected paperback edition.

Samuelson, William.: 1984, "Bargaining Under Asymmetric Information," Econometrica, 52, 995-1005.

Scheppele, Kim Lane.: 1988, Legal Secrets: Equality and Efficiency In the Common Law (University of Chicago Press, Chicago). 
Shell, G. Richard.: 1990, "When is it Legal to Lie in Negotiations?" Sloan Management Review, forthcoming.

Story, Joseph. 1886. Commentaries on Equity Jurisprudence as Administered in England and America, 13th ed. Revised by Melville M. Bigelow (Little, Brown, and Company, Boston).

Taylor, Michael.: 1982, Community, Anarchy, and Liberty (Cambridge University Press, New York).

White, James 1.: 1980, "Machiavelli and the Bar: Ethical Limitations on Lying in Negotiation," American Bar Foundation Research Journal, 1980,926-938.

Wilson, Robert.: 1985, "Reputations in Games and Markets." In Alvin Roth, ed., Game Theoretic Models of Bargaining (Cambridge University Press, New York).

Zucker, Lynne G.: 1986, "Production of Trust: Institutional Sources of Economic Structure, 1840-1920." Research in Organizational Behavior, 8, 53-111 (JAI Press, Greenwich). 